\title{
LEGIONNAIRES' DISEASE IN THE RENAL TRANSPLANT UNIT OF “HOSPITAL DAS CLINICAS, FMUSP". DURING A FIVE YEAR PERIOD (1988-1993)
}

\author{
Neusa Augusta de Oliveira MAZIERI (1), Cid Vieira Franco de GODOY (2), Solange Figueiredo ALVES (3), \\ Dahir Ramos de ANDRADE (4), Ana Sara S. LEVIN (5) \& Ana Cristina IIABLITZEL (6).
}

\begin{abstract}
SUMMARY
Several reports have related Legionella pneumophila with pneumonia in renal transplant patients, however this association has not been systematically documented in Brazil. Therefore this paper reports the incidence, by serologycal assays, of Legionella pneumophila serogroup 1 in these patients during a five year period. For this purpose sera from blood samples of 70 hospitalized patients with pneumonia from the Renal Transplant Unit of Hospital das Clinicas, FMUSP collected at the acute and convalescent phase of infection were submitted to indirect immunofluorescence assay (IFA) to demonstrate anti-Legionella pneumophila serogroup 1 antibodies. Of these 70 patients studied during the period of 1988 to $1993,18(25.71 \%)$ had significant rises in specific antibody titers for Legionella pneumophila serogroup 1. Incidence was interrupted following Hospital water decontamination procedures, with recurrence of infections after treatment interruption. In this study, the high susceptibility (25.71\%) of immunodepressed renal transplant patients to Legionella pneumophila serogroup 1 nosocomial infections is documented. The importance of the implementation and maintenance of water decontamination measures for prophylaxis of the infection is also clearly evident.
\end{abstract}

KEYWORDS: Legionnaires' disease; Renal transplant unit.

\section{INTRODUCTION}

The association of Legionella pneumophila with pulmonary infections in patients submitted to renal transplantations has been reported by several investigators (AGUILAR et al. "; AMPEL \& WING ${ }^{2}$; BOCK et al. ${ }^{4}$; FOSTER et al. ${ }^{12}$; HALEY et al. ${ }^{16}$; MARSHALL et al. ${ }^{21}$; TOBIN et al. ${ }^{35}$ ). In Brazil, publications regarding Legionella sp. are related to clinical descriptions (BETHLEM \& GUSMÃO ${ }^{3}$; DE PAULA et al. ${ }^{8}$;;
PEREIRA E SILVA ${ }^{3 !}$; PORTO et al. ${ }^{34}$ ), serological survey in blood donors and intensive care units staff (VERONESI ${ }^{36}$ ), isolation from a community acquired case (PEREIRA GOMES et al. ${ }^{33}$ ), renal transplant unit (LEVIN et al. ${ }^{19}$, MAZIERI ${ }^{22}$; MAZIERI et al. ${ }^{25}$ ) and finally Legionella spp isolation from nosocomial and industrial environment (PELLIZARI ${ }^{30}$ ). The positive results of these initial studies in this country motivated

(1) Farmacêutica - Bioquímica, Laboratório de Investigação Médica (LIM-54). Hospital das Clínicas da Faculdade de Medicina da Universidade de São Paulo (HC-FMUSP). São Paulo, Brazil.

(2) Prof. Resp. Disc. Patol. Clínica, Departamento de Patologia da FMUSP, LIM-54 e Instituto de Medicina Tropical de São Paulo, S. P., Brazil.

(3) FMUSP, LIM-54, HC-FMUSP.

(4) Diretor Clinico do Dep. de Moléstias Infecciosas e Parasitánias do HC-FMUSP e chefe do LIM-54, Bacteriologia.

(5) Membro da Comissão de Infecções do ICHC-FMUSP.

(6) Prof. Adj. Microbiologia - Universidade de Mogi das Cruzes.

Endereço para correspondência: Neusa Augusta de Oliveira Mazieri - Rua Fernão Dias 128, apto. 191 - Pinheiros, São Paulo, Brazil. CEP $05427-000$. 
MAZIERI, N. A. de O.; GODOY, C. V. F. de; ALVES, S. F.; ANDRADE, D. R. de; LEVIN, A. S. S. \& HABLITZEL, A. C. - Legionnaires' disease in the Renal Transplant Unit of "Hospital das Clínicas, FMUSP", during a five year period (1988-1993). Rev. Inst. Med. trop. S. Paulo 36( 3):231-236, 1994.

the present study with immunodeppressed patients, specifically with patients in the renal transplant unit of Hospital das Clinicas, Faculdade de Medicina, of the University of São Paulo.

\section{METHODS}

From a total number of 250 patients with pulmonary infections in Hospital das Clinicas, submitted to specific laboratory tests for legionellosis, during the period of July, 1988 to July, 1993, 70 were renal transplant subjects.

Antibody testing for Legionella pneumophilia serogroup 1 were carried out by the indirect immunofluorescence test in paired sera collected in the acute and convalescent phase of the disease, using the heat-inactivated Legionella pneumophila serogroup 1 (Philadelphia) strain and anti-human polyvalent immunoglobulins (IgA, IgM and IgG) conjugate (MAZIERI ${ }^{22}$; WILKINSON ${ }^{37}$ ). Recommendations from Centers for
Disease Control (WILKINSON ${ }^{37}$ ) were followed to interpret results: a fourfold antibody titer rise in paired sera or significant titer equal to or above 256 when accompanied by agent isolation.

\section{RESULTS}

Of the 70 hospitalized patients studied in the Renal

\section{TABLE 1}

Annual distribution of incidence of Legionnaires'Disease (LD) at the Renal Transplant Unit (RTU) and pulmonary infections at RTU and other units of Hospital das Clinicas da Faculdade de Medicina, University of São Paulo (HC-FMUSP).

\begin{tabular}{lccrr}
\hline Year & $\begin{array}{c}\text { cases of } \\
\text { pneumonia } \\
\text { HC-FMUSP }\end{array}$ & $\begin{array}{c}\text { cases of } \\
\text { pneumonia } \\
\text { RTU }\end{array}$ & \multicolumn{2}{c}{$\begin{array}{c}\text { incidence } \\
\text { of } \\
\text { LD (RTU) }\end{array}$} \\
\hline $1988 / 1989$ & 26 & 0 & 0 & $(0 \%)$ \\
$1989 / 1990$ & 53 & 29 & 9 & $(31.03 \%)$ \\
$1990 / 1991$ & 63 & 19 & 2 & $(10.52 \%)$ \\
$1991 / 1992$ & 78 & 17 & 7 & $(41.17 \%)$ \\
$1992 / 1993$ & 30 & 5 & 0 & $(0 \%)$ \\
\hline
\end{tabular}

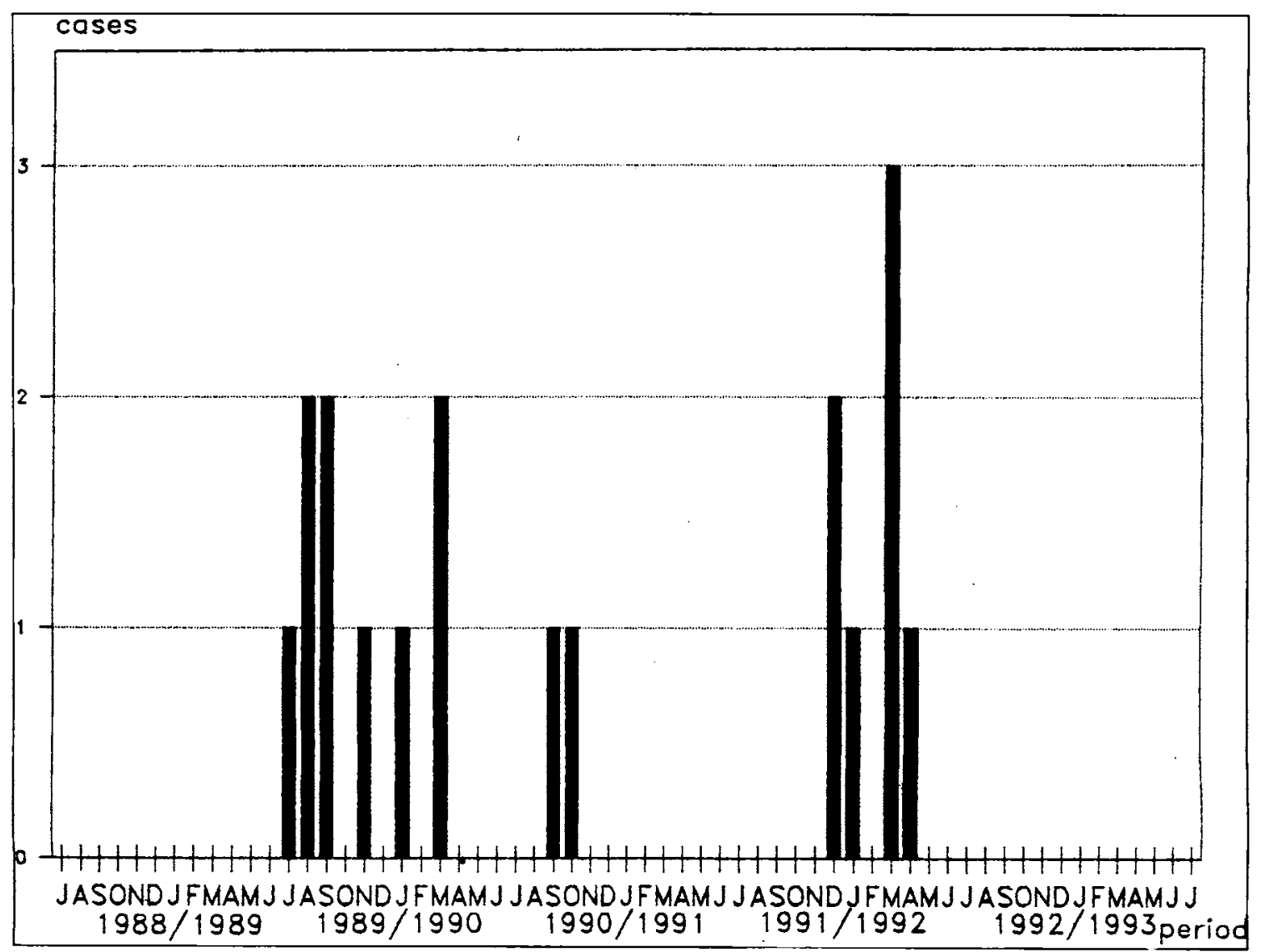

Figure 1 - Monthly distribution of cases of Legionnaires' Disease at the Renal Transplant Lnit (KIL). Huspital das Clinicas da Faculdade de Medicina, University of São Paulo (IIC-FMUSP), during July 1988 to July 1993. 
MAZIERI, N. A. de O.; GODOY, C. V. F. de; ALVES, S. F.; ANDRADE, D. R. de; LEVIN, A. S. S. \& HABLITZEL, A. C. - Legionnaires' disease in the Renal Transplant Unit of "Hospital das Clinicas, FMUSP", during a five year period (1988-1993). Rev. Inst. Med. trop. S. Paulo 36( 3):231-236, 1994.

Transplant Unit (RTU) during the period of July 1988 to July 1993 with pulmonary infections, $18(25.71 \%)$ presented significant specific sera antibody titers to Legionella pneumophila serogroup 1. The incidence, monthly and annual distribution of the cases are shown in table 1 and figures 1 and 2 .

\section{DISCUSSION}

The precise incidence of legionellosis in the population has not been yet determined (W. H. O., ${ }^{38}$ ). Preventive measures are recommended to avoid legionella contamination in areas where patients may be more susceptible (ENGLAND \& FRASER ${ }^{11}$; GARBE et al. ${ }^{13}$, KIRBY et al. ${ }^{18}$, LOWRY \& TOMPKINS ${ }^{20}$; MUDER et al. ${ }^{28}$; NEIL et al. ${ }^{29}$ ) such as immunodepressed patients due to illness, age or therapy (radiation therapy, anticancer or immunodepressive drugs). Fatality rates of Legionnaires'Disease are more elevated in these nosocomial cases (30-50\%) than in community-acquired cases. This fact is thoroughly comprehensible, for in Hospitals, besides the contamination source there are high risk subjects to acquire the infection. In hospital- ized populations, that are exposed to the agent, predective values for attack rate and mortality are high (W. H. O. ${ }^{38}$ ).

Water system (mainly heated water) are common sources of infection: these systems are usually of major complexity, mainly in hospital edifications that were enlarged or modified. The site of legionella propagation may be water ontlets such as faucets (BOLLIN et al. ${ }^{5}$ ), showers (DENNIS et al. ${ }^{9}$, TOBIN et al. ${ }^{35}$ ), bathtubs (BOLLIN et al. ${ }^{5}$ ), cooling towers (DONDERO et al. ${ }^{10}$; KLAUCHE et al. ${ }^{17}$; MITCHELL et al. ${ }^{27}$ ), condensed water collector trays from airconditioning systems (LEVIN et al ${ }^{19}$ ), plumbing system shock absorbers (MEMISIl et al. ${ }^{26}$ ), etc.

When the present study was initiated, following isolation of the agent on January, 1988 (PEREIRA GOMES et al. ${ }^{33}$ ) the association of the importance of legionella in the immunodepressed was not yet known.

A total of 26 cases were initially received in our laboratory as legionellosis suspects from several wards of the Hospital das Clinicas da Faculdade de Medicina

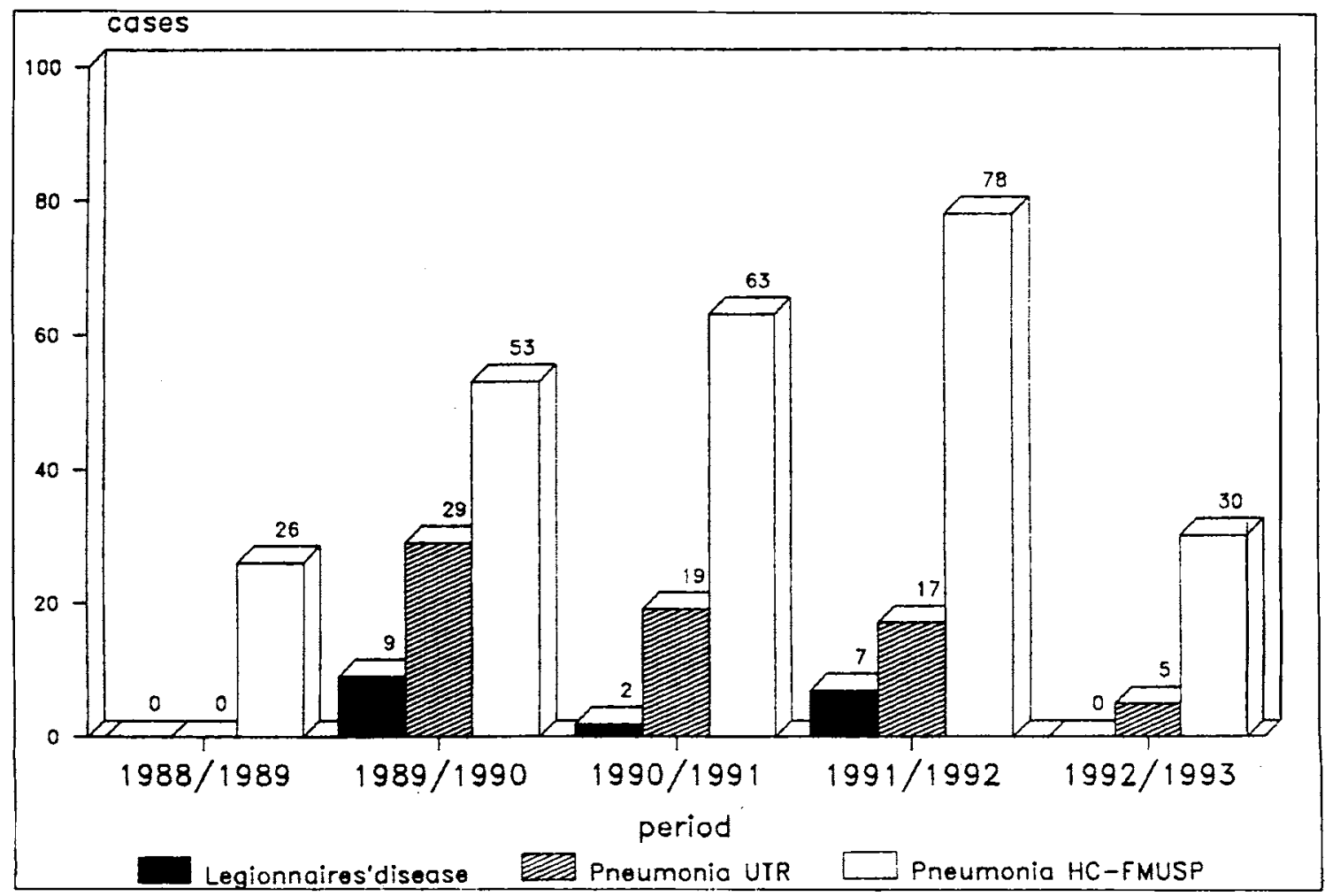

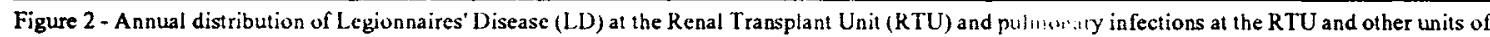
Hospital das Clinicas, University of São Paulo (HC-FMUSP). 
USP, none proceeding however from the Renal Transplant Unit.

As a consequence of the divulgation of the role of Legionnaires' Disease in pneumonias in our country, through papers presented in several Medical Meetings: Brazilian Congress of Pneumology and Tisiology (Curitiba, 1988) ${ }^{32}$, Brazilian Congress of Clinical Pathology (Rio de Janeiro, 1989) ${ }^{25}$ and the Scientific Meeting of Tropical Medicine Institute of São Paulo (São Paulo, 1989) ${ }^{14,23,24}$ a consensus of the application of laboratory procedures for diagnostic elucidation was accepted by our Medical Community.

Biological specimens from pneumonia patients in the Renal Transplant Unit of Hospital das Clinicas began arriving to our laboratory and in the following year (July 1989 to July 1990) of the twenty nine patients with pneumonia belonging to this Unit, 9 (31.03\%) were diagnosed by laboratory procedures as Legionnaires' Disease.

Decontamination measures in the hospital water system were introduced, by hyperchloration (6-10 ppm) and heating $(80 \mathrm{C})$ as described by LEVIN et al. ${ }^{19}$.

At this time, microbiological analyses were performed in the hospital water system, with recovery of Legionella pneumophila serogroup 1 from the condensed water collection tray of the air conditioning system by LEVIN et al. ${ }^{19}$ and from the water reservoir and the residue of the electric boiler, by PELLIZARI ${ }^{30}$.

Five months following the first decontamination (in April 1990) of the hospital water system, 2 new cases of Legionellosis were diagnosed (September and October, 1990). A new decontamination by hyperchloration (6-10 ppm) was conducted and repeated after a period of five months. As a result of these procedures a period of 12 months prevailed without new cases of legionellosis. From December 1991 to April 1992, 7 new cases of the infection with pneumonia were diagnosed, and three among these had irrefutable evidence of hospital acquired legionellosis (Legionella pneumophila serogroup 1).

Prophylactyc procedures were performed continuously with five months intervals by hyperchloration (10 $\mathrm{ppm}$ ) with no further legionellosis to this date at the Hospital das Clinicas.

Of the total of 76 patients with pneumonia from the
Renal Transplant Unit of Hospital das Clinicas, 18 $(25.71 \%)$ had laboratory diagnosis of legionellosis in a five year period (Figure 2).

Considering the low number of cases from a statystical point of view, Legionnaires' Disease incidence according to season or months of the year was not applicable to statistical evaluation but intervals between infection were clearly related to decontamination procedures. Following the nosocomial outbreak at Hospital das Clinicas from December 1991 to April 1992, it was evident that control measures were extremely necessary for an active surveillance of the disease in the exposed population, with good results to this date of the implementation of decontamination procedures.

World literature has references to surveillance of infection sources determining as causes of legionellosis outbreaks, the failure to implement control measures, descontinuation or interruption of these procedures, demonstrating the importance of monitoring water quality systematically (W.H.O. ${ }^{38}$ ). Once water treatment is introduced, it must necessarily be continuous, as bacteria reappearance is common with possibility of manifestation of clinical disease (BORNSTEIN et al. ${ }^{6}$; COLVILLE et al. ${ }^{7}$; GROOTIUUIS et al. ${ }^{15}$; KLAUCKE et al. ${ }^{17}$ ).

\section{CONCLUSIONS}

- In the patient group included in this study, high susceptibility $(25.71 \%)$ to nosocomial infection by Legionella pneumophila serogroup 1 of this immunodepressed renal transplant population was documented.

- The results of this study and the incidence distributions recorded support the importance of microbiological surveillance as water reservoirs and nosocomial water systems and the maintenance of continuous measures to minimize legionellosis propagation.

\section{RESUMO}

Doença dos legionários na Unidade de Transplante Renal (UTR) do Hospital das Clínicas FMUSP, no período de 1988 a 1993.

Embora vários trabalhos tem mostrado a presença de Legionella pneumophila associado a pneumopatias infecciosas em transplantados renais, tal associação não fora antes realizado de maneira sistemática no Brasil. Os autores julgaram oportuno a determinação 
MAZIERI, N. A. de 0.; GODOY, C. V.F. de; ALVES, S. F,; ANDRADE, D. R. de; LEVIN, A. S. S. \& HABLITZEL, A. C. - Legionnaires' disease in the Renal Transplant Unit of "Hospital das Clínicas, FMUSP", during a five year period (1988-1993). Rev. Inst. Med. trop. S. Paulo 36( 3):231-236, 1994.

da incidência por comprovação sorológica da Legionella pneumophila sorogrupo 1 em transplantados renais num periodo de 5 anos.

Para tanto amostras de soros de 70 pacientes com pneumopatia infecciosa internados na UTR do HCFMUSP, colhidos na fase aguda e convalescente da infeç̧ão, foram submetidas à reação de imunofluorescência indireta para pesquisa de anticorpos antiLegionella pneumophila sorogrupo 1.

Dos 70 pacientes transplantados renais com pneumopatia infecciosa estudados no período de 1988 a 1993, 18 (25.71\%) apresentaram amostras de soros com aumento significante de títulos de anticorpos específicos para Legionella pneumophilia sorogrupo 1.

A distribuição da incidência dos casos foi interrompida após medidas de descontaminação da água do nosocômio, com reincidência após a interrupção deste tratamento.

Verificaram os autores com os pacientes incluídos neste estudo a elevada suscetibilidade $(25,71 \%)$ dos imunedeprimidos transplantados renais às infecções nosocomiais por Legionella pneumophila sorogrupo 1. Ressaltam ainda, a importância na implementação e manutenção de medidas de descontaminação da água para a profilaxia da infeç̧ão.

\section{REFERENCES}

1. AGUILAR, B. X.; ROIG, C. J.; TEXIDO, B. A. et al. - Nosocomial legionellosis: study of 51 cases. Med. clín. (Barcelona), 93: 125 128, 1989.

2. AMPEL, N. M. \& WING, E. J. - Legionella infection in transplant patients. Sem. Resp. Infect., 5: 30-37, 1990.

3. BETHLEM, N. \& GUSMÃO, J. M. - Descrição de um caso de pneumonia por Legionella pneumophila. J. Pneum., 8(supl.): 207, 1982.

4. BOCK, B. V.; EDELSTEIN, P. H.; SNYDER, K. M. et al. Legionnaires' disease in renal-transplant recipients. Lancet, 1 : 410-413, 1978.

5. BOLLIN, G. E.; PLOUFFE, J. F.; PARA, M. F. \& HACKMAN, B. Aerosols containing Legionella pneumophila generated by shower heads and hot-water faucets. Appl. environ. Microbiol., 50: 1128$1131,1985$.

6. BORNSTEIN, N.; VIEILLY, C.; NOWICKI, M.; PAUCOD, J. C. \& FLEURETTE, J. - Epidemiological evidence of legionellosis transmission through domestic hot water supply systems and possibilities of control. Isr. J. med. Sci., 22: 655-661, 1986.
7. COLVILLE, A.; CROWLEY, J.; DEARDEN, D.; SLACK, R. C. \& LEE, J. V. - Outbreak of Legionnaires' disease at University Hospital, Nottingham. Epidemiology, microbiology and control. Epidem. Infect., 110: 105-116, 1993.

8. DE PAULA, A. B.; CALAZANS, C. A. C.; VILELA, A. L. \& PEREIRA, E. - Doença dos Legionários em Itatinga, M.G. In: CONGRESSO BRASILEIRO DE INFECTOLOGIA, 3., Petrópolis, 1986. Anais. p. 79.

9. DENNIS, P. J.; WRIGHT, A. E; RUTTER, D. A.; DEATH, J. E. \& JONES, B. P. - Legionella pneumophila in aerosols from shower baths. J. IIyg. (Lond)., 93: 349-353, 1984.

10. DONDERO JR., T. J.; RENDTORFF, R. C.; MALLISON, G. F. et al. - An outbreak of Legionnaires' disease associated with a contaminated air-conditioning cooling tower. New Engl. J. Med., 302: $365-370,1980$.

11. ENGLAND, A. C. \& FRASER, D. W. - Sporadic and epidemic nosocomial Legionellosis in the United States. Amer. J. Med., 70: 707-711, 1981.

12. FOSTER JR., R. S.; WIMN, W. C.; MARSLLAL, W. \& GUMP, D. W. - Legionnaires' disease following renal transplantation. Transplant. Proc., 11: 93-95, 1979.

13. GARBE, P. L.; DAVIS, B. J.; WHISFELD, J. S. et al. - Nosocomial Legionnaires' disease. Epidemiologic demonstration of cooling towers as a source. J. Amer. wed. Ass., 254: 521-524, 1984.

14. GODOY, C. V. F.; MAZIERI, N. A. O.; ROCIIA, A. S.; PEREIRA GOMES, J. C. \& VERONESI, R. - Incidência de Legionella pneumophila sorogrupo $1 \mathrm{em}$ pacientes com peneumopatia atípica no Hospital das Clinicas FMUSP. In: JORNADA CIENTIFICA DO INSTITUTO DE MEDICINA TROPICAL DE SÃO PAULO, 3., São Paulo, 1989. (Rev. Inst. Med. trop. S. Paulo, 31 (supl. 7): 96, 1989).

15. GROOTHUIS, D. G.; HAVELAAR, A. H. \& VEENENDAAL, H. R. - A note on Legionellas in whirlpools. J. appl. Bact., 58: 479-481, 1985.

16. HALEY, C. E.; COHEN, M. L.; HALTER, J. \& MEYER, R. O. Nosocomial Legionnaires' disease: a continuing common-source epidemic at Wadsworth Medical Center. Ann. intern. Med., 90: 583-586, 1979.

17. KLAUCIIE, D. N.; VOGT, R. L.; LaRUE, D. et al. - Legionnaires' disease: the epidemiology of two outbreaks in Burlington, Vermont, 1980. Amer. J. Epidem., 119: 382-391, 1984.

18. KYRBY, B. D.; SNYDER, K. M; MEYER, R. D. \& FINEGOLD, S. $M$. - Legionnaires' disease: report of sixty-five nosocomially acquired cases of review of the literature. Medicine (Baitimore), 59: 188-205, 1980.

19. LEVIN, A. S. S.; CAIAFFA FILIIO, H. H.; SINTO, S. I. et al. - An outbreak of nosocomial Legionnaires' disease in a renal transplant unit in São Pawo, Brazil. J. Ilosp. Infect., 18: 243-248, 1991.

20. LOWRY, P. W. \& TOMPKINS, L. S. - Nosocomial legionellosis: a review of pulmonary and extra pulmonary syndromes. Amer. J. infect. Control, 21: 21-27, 1993.

21. MARSHALL, W. R.; FOSTER JR, R. S. \& WINN, W. - Legionnaires' 
MAZIERI, N. A. de O.; GODOY, C. V. F. de; ALVES, S. F.; ANDRADE, D. R. de; LEVIN, A. S. S. \& HABLITZEL, A. C. - Legionnaires' disease in the Renal Transplant Unit of "Hospital das Clínicas, FMUSP", during a five year period (1988-1993). Rev. Inst. Med. trop. S. Paulo 36( 3):231-236, 1994.

disease in renal transplant patients. Amer. J. Surg., 141: 423-429, 1981 .

22. MAZIERI, N. A. O. - Legionelose associada a pneumopatias em São Paulo. Estudo da comprovação etiológica por isolamento $e$ sorologia. São Paulo, 1990. (Dissertação de Mestrado-Instituto de Ciências Biomédicas da Universidade de São Paulo).

23. MAZIERI, N. A. O.; GODOY, C. V. F.; PEREIRA GOMES, J. C.; ROCHA, A. S. \& VERONESI, R. - Legionella pneumophila: primeiro caso de isolamento no Brasil. In: JORNADA CIENTIFICA DO INSTITUTO DE MEDICINA TROPICAL DE SÃO PAULO, 3., São Paulo, 1989. (Rev. Inst. Med. trop. S. Puulo, 31 (supl. 7): 96, 1989).

24. MAZIERI, N. A. O.; HABLITZEL, A. C.; DIAS, M. B. G. S. et al. Imunofluorescência indireta para Legionella pneumophila sorogrupo $1 \mathrm{em} 100$ casos de pneumopatias infecciosas do Hospital Universitário (USP). In: JORNADA CIENTIFICA DO INSTITUTO DE MEDICINA TROPICAL DE SÃo PAULO, 3, São Paulo, 1989. (Rev. Inst. Med. trop. S. Paulo, 31 (supl. 7): 97. 1989).

25. MAZIERI, N. A. O.; LEVIN, A. S. C.; IERMINIO, J. M. A.; SABBAGA, E. \& GODOY, C. V. F. - Infecção por Legionella pneumophila sorogrupo $1 \mathrm{em}$ transplantados renais portadores de pneumopatia infecciosa. In: CONGRESSO BRASILEIRO DE PATOLOGIA CLÍNICA, 24., São Paulo, 1990. Anais. p. 71.

26. MEMISH, Z. A.; OXIEY, C.; CONTANT, J. \& GARBER, G. E. Plumbing system shock absorbers as a source of Legionella pneumophila. Amer. J. infect. Control, 20: 305-309, 1992.

27. MITCHELL, E.; O'MAHONY, M.; WATSON, J. M. et al. - Two outbreaks of Legionnaires' disease in Boston Health District. Epidem. Infect., 104: 159-170, 1990.

28. MUDER, R. R.; YU, V. L.; McCLURE, J. K. et al. - Nosocomial Legionnaires' disease uncovered in a prospective pneumonia study. J. Amer. med. Ass., 249: 3184-3188, 1983.

29. NEIL, N. A.; GORMAN, G. W.; GIBERT, C. et al. - Nosocomia! Legionellosis, Paris, France. Evidence for transmission by potable water. Amer. J. Med., 78: 581-588, 1985.
30. PELLIZARI, V. H. - Investigação sobre a ocorrência de Legionella $s p p$ em águas provenientes de residências, prédios públicos e de ambientes hospitalares e industriais. São Paulo, 1991. (Dissertação de Mestrado - Instituto de Ciências Biomédicas da Universidade de São Paulo).

31. PEREIRA E SILVA, J. L. - Doença dos Legionários: relato do primeiro caso do Brasil. J. Pneumol., 11: 26-30, 1985.

32. PEREIRA GOMES, J. C.; GODOY, C. V. F.; MAZIIRI, N. A. O. \& ROCHA, A. S. - Síndrome do desconforto respiratório do adulto (SIDRA) por Legionella pneumophila comprovada por isolamento e sorologia. In: CONGRESSO BRASILEIRO DE PNEUMOLOGIA E TISIOLOGIA, 24, Curitiba, 1988 .

33. PEREIRA GOMES, J. C.; MAZIERI, N. A. O.; GODOY, C. V. F. \& ROCIIA, A. S. - Legionella pneumophila associada a insuficiência respiratória aguda. Primeiro isolamento no Brasil. Rev. Inst. Med. trop. S. Paulo, 31: 368-376, 1989.

34. PORTO, N. S.; PALOMBINI, B. C.; PETRILLO, V. F. \& ALVES, M. R. A. - Pneumonia por Legionella pneumophila: relato do segundo caso brasileiro. Rev. Inst. Med. trop. S. Paulo, 28: 368-370, 1986.

35. TOBIN, J. O. H.; DUNNILL, M. S.; FRENCH, M. et al. - Legionnaires's disease in a transplant unit: isolation of the causative agent from shower baths. Lancet, 1: 118-121, 1980.

36. VERONESI, R.; BARBOSA, S. F. C.; COSCINA, A. L. \& LIMA, A C. C. - Legionelose no Brasil. Inquérito sorológico entre doadores de sangue $\mathrm{e}$ trabalhadores em unidades de terapia intensiva de três hospitais de São Paulo. Rev. Hosp. Clín. Fac. Med. Univ. S. Paulo, 3: 257-259, 1984.

37. WILKINSON, H. W. - Hospital - Laboratory diagnosis of legionella infections. Atlanta, Centers for Disease Control, 1987. p. 1-42.

38. WORLD IIEALTH ORGANIZATION - Epidemiology, prevention and control of legionellosis: memorandum from a WHO meeting. Bull. Wld. Hlth. Org., 68: 155-164, 1990.

Recebido para publicação em 07/10/1993. Aceito para publicação em 18/11/1993. 